\title{
南極における空中写真測量
}

\author{
鍛 治 晃 $\Xi^{*}$

\section{Report on the Aerial Surveying of Japanese Antarctic Research Expedition}

By

\section{Teruzo KUJI}

\begin{abstract}
(Abstract)
Aerial photography started on 14 th of January and finished on 13 th of February and only nine flights could be done in this duration. 750 sheets of vertical photograph by K 17 camera and 450 sheets of oblique photograph by F 24 camera had been taken over approximately of 2,000 flying miles. The average flying altitude for vertical photography was 5,000 feet and that for oblique photography was 3,000 feet. In such ways, the coast of Prince Harald Land and Prince Olav could be photographed.

The author would like to suggest the following equipment and operation procedures from my experience.

Aeroplane; Although the Cessna 180 gave us rather good service, I would not recommend it for aerial photography in Antarctica. I would advocate a bigger aeroplane and if possible, a high wing, and twine engine aeroplane.

Camera; The $\mathrm{K} 17 \mathrm{C}$ camera with lens of six inches focal length has a heating jacket, magazine heater and heating wires on filter, but these were not necessary for our operation. In the author's opinion, a new instrument should be installed to be automatically operated for recording the number, time, altitude, air speed, and the bearing of the plane at each exposure for vertical photography.

Film; The film used Eastman Kodak super XX Aerographic Film $(9.5$ inches $\times 150$ feet roll) and Sakura Aero Film $(5.5$ inches $\times 56$ feet roll) These films were quite satisfactory for our photography.

Exposure and Filter; Most of the vertical photographs were exposured at 1/400 second and F : 11 or F : 8 with No. 2 Aero vignetted filter, but the heating wires on the filter were not used.

Development and Printing; Development and Printing had been carried out on our ship in the Antarctic. All rolls of film were developed in D76 Developer under the condition of $20^{\circ} \mathrm{C}$ and about 30 minutes in B-5 Developing Kit. Drying Kit was not nsed for drying.
\end{abstract}

* 地理調查所, 地学襍誌 Vol. 66 No.3 (705), 1957 


\section{I 序}

日本学術会議において国際地球観測年の一事業として南極観測の実施を決定し, その一部門として地㘡 作成の仕事を行らことを計画し始めたのは昭和 30 年の秋であつた。日本の約 37 倍もある南極大陸の一角 飞基地泣作り，こっで各種の観測を行うわけであるが，地図を作るといらことになるとある程度まとまつ た地域の地図を作らなくてはたいして意味のないことである。しかし仕事を行える期間はせいぜいエカ月 という短期間であり, この短期間にある地域の測量を行うためにはどうしても空中写真測量を行わなくて は他に方法がないといってもよい。

1928 年オーストラリアのウイルキンスによつて行われた南極に拈ける初飛行, 次いで翌年の 1929 年バ 一ドによつて行われた南極点への飛行成功以来, 南極探検は航空機時代に大り空中写真測量が 次から次へ と行われた。

その主なるものを数えても，1937 年のノルウェー隊，1938～39 年のドイッ隊，1946 年以来の米国豚， 1955 年の英国隊等各国の探検隊が南極大陸で空中撮影を行つている。

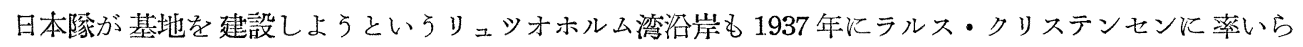
れたノルウェー陵のビイゴー・ウイドレー(飛行士) とニルス・ロムナス(撮影士) が 2 月 4 日から 5 日まで に2 回にわたつて飛行を行い，2月5日に空中写真撮影を行つている。

この時, 針用した飛行機はスティンソン機で, これは 350 馬力, 速度 $200 \mathrm{~km} / \mathrm{h}$, 航続距離 $1,200 \mathrm{~km}$ であり, 空中写真機はッアイスの R. M. K. 21/18 を使用して斜写真を $1,400 〜 2,000 \mathrm{~m}$ の高度で撮つて いる。これは計画では $3,000 \mathrm{~m}$ から撮る予定であつたが重装備のため実際は上記のような低い高度から 撮らざるを得なかつた。その後，この写真を利用して 25 万分 1 の図を作つている。

また过は米国の第 68 機動部隊が撮影したもので，これは $\mathrm{K} 17$ 空中写真機を便用，トリメトロゴン方 式で $10,000 \mathrm{ft}$. の高度で撮影を行つている。

幸いにこの两方の写真は出発前に永田隊長と西堀副陵長の努力によつて入手することができ, 出発前及 び往路の船上でできるかぎりの調査を行つた。この二つの資料を主として他の記録を調べ，色々と迷いな がら南極を想像して準備と計画を行つたのである。

\section{II. 計画と準 備}

前述のように空中写真測量が各国で行われているのであるが，さて，日本隊が行らとなるとどの程度の ことを行らか，またどらいう方法で行らかが種々の点から检討された。

地図を作る以上はできるだけ広い範囲の地図を作りたい。しかし，米国が行つているよらなスカイマス ター, ネプチューン, ビーチクラフト等の大型飛行機を用いて大規模に撮影を行らことは, 到底実行不可 能である。英国がグラハムランドで行つたカンソー水陸両用飛行艇を用いての測量程度すら塞行困難であ る。そこで一応，1956 57 年の予備観測に打ける飛行機の任務を次のよ5に用いると限定して飛行機の機 種を決めることにした。

1. 流水中を通る船の水路の偵察 2 . 大陸沿岸の上陸, 基地建設に適する地域の調査・偵察 3 . 基 地を中心とした地域の空中写真測量

このような役割を果すための条件として, 水上機として使用でき, またスキー付飛行機に簡単に変えら れること，極地飛行に耐えるような装備をそなえられること，空中写真撮影が行えること，その他種々の 条件を考光あわせ，日本航空学会の特別委員会で検討の結果，カナがの $\mathrm{D} \cdot \mathrm{H} \cdot \mathrm{C}$ ビーバー機が推選され た。

この飛行機は献極において各国が使用して拉り，出発前に大手の可能性もあるとのことで決められたも 
のである。

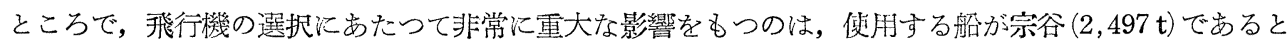
いうこと，そしてこの船が 11 月初旬に日本を出発，そのため準備期間が半年しかないということ，乙か も船上では特別の改装や設備を行う人員・設備の準備がなく，船上での改装は不可能であるということ， そして日本から南極まで船に積んで運びすぐ使用できる状態にしておかなければならないということであ る。

宗谷で 53 人の観測陵員とその生活に必要な物資・科学観測器材，括よび可能ならば，基地をつくり越 冬隊を残すための資材・燃料を積み，その上ビーバーを積んで南極をで出かけ，水上機として飛ばすこと は, あらゆる方面から検討された結果, 船の運航上不可能であるという結論が出された。そこで次の方法 として，宗谷に積載可能でしかも出発までに間に合う飛行機ということになつたのであるが，あう時間が ないために国内にある飛行機で大手可能な飛行機をさがすということになり，三三の機種が話題に上つた 結果，セスナ 180 型が撰ばれ，新日新聞社の「さら風」を使用することに決定した。この時すでに 7 月末に なつていた。

セスナ 180 水上機の性能は次の通りである。

$\begin{array}{cccc}\text { 最大重量 } & 1,280 \mathrm{~kg} & \text { 空 虚 重 量 } & 798 \mathrm{~kg} \\ \text { 積 載 重 量 } & 482 \mathrm{~kg}(1,060 \mathrm{lb}) & \text { 最高 速度 } & 232 \mathrm{~km} / \mathrm{h} \\ \text { 巡行 速 度 } & 216 \mathrm{~km} / \mathrm{h} & \text { 実用上昇限度 } & 6,040 \mathrm{~m}\end{array}$

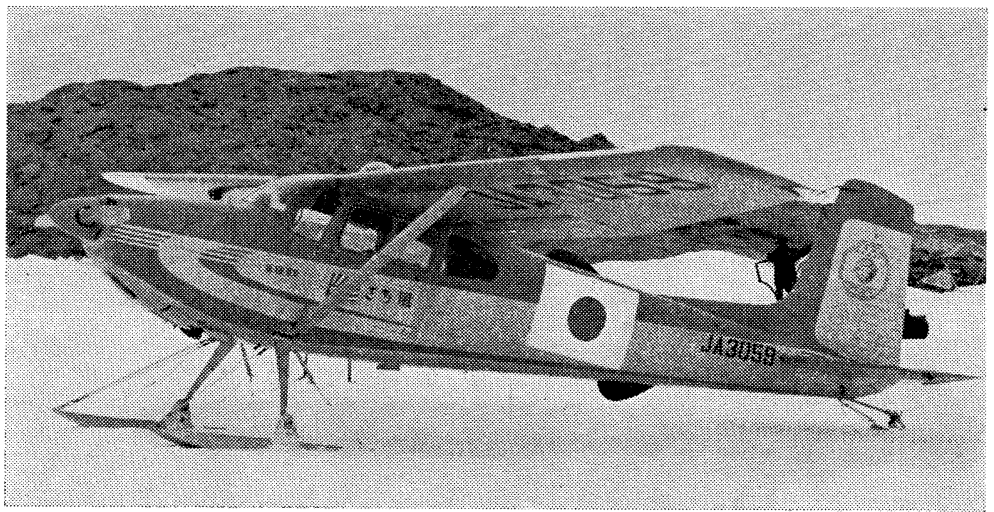

写真 1 西オングル島附近に着陸したセスナ 180 「さち風」

\begin{tabular}{|c|c|c|c|}
\hline 続 距 離 & $1,830 \mathrm{~km}$ & 航 続 時 間 & 4 時間 30 分 \\
\hline 水 距 離 & $1,830 \mathrm{ft}$ & 着 水 距 離 & $670 \mathrm{ft}$ \\
\hline 料 & 55 gal & 燃料消費量 & $11.5 \mathrm{gal} / \mathrm{h}$ \\
\hline
\end{tabular}

積載量の内訳

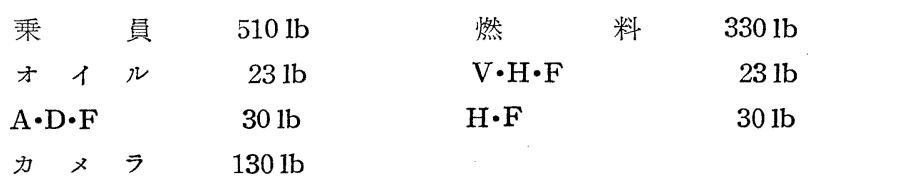

ところで，朝日新聞社の「さち風」は水上機であり，フロート・スキーを至急朄より輸大するととも に，日本航空整備株式会社で，極地用として，また写真撮影が行えるよう改装に着手した。 


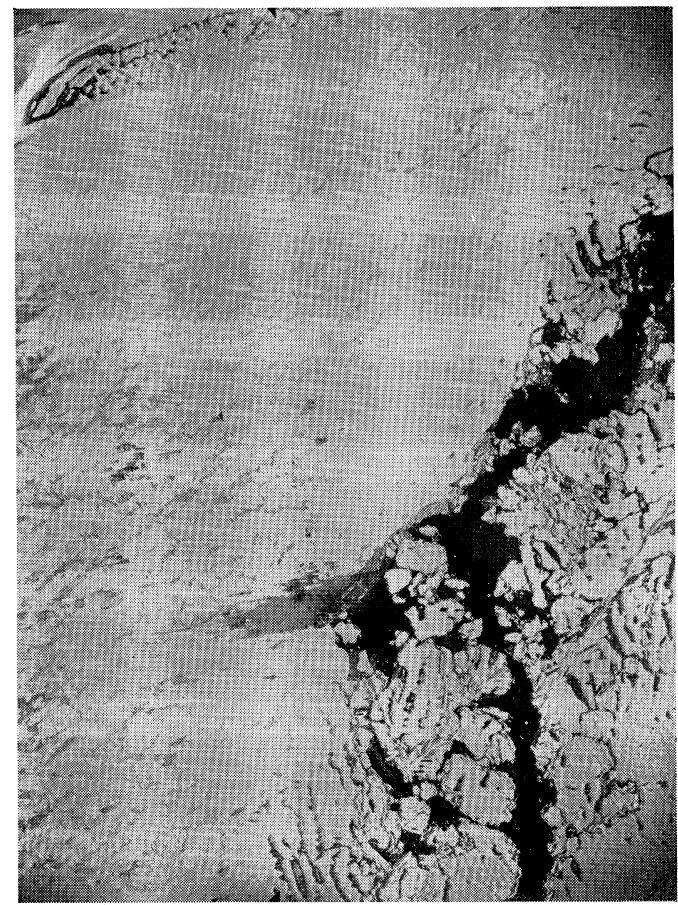

宗谷の接岸

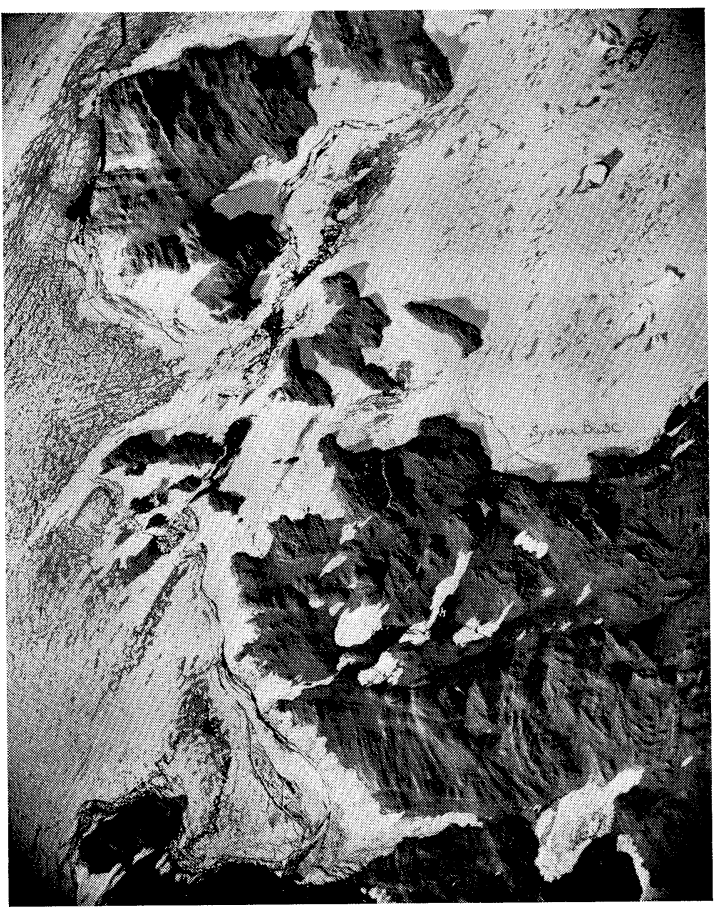

オングル島昭和基地附近（縮尺 約 24,000 分の 1) 


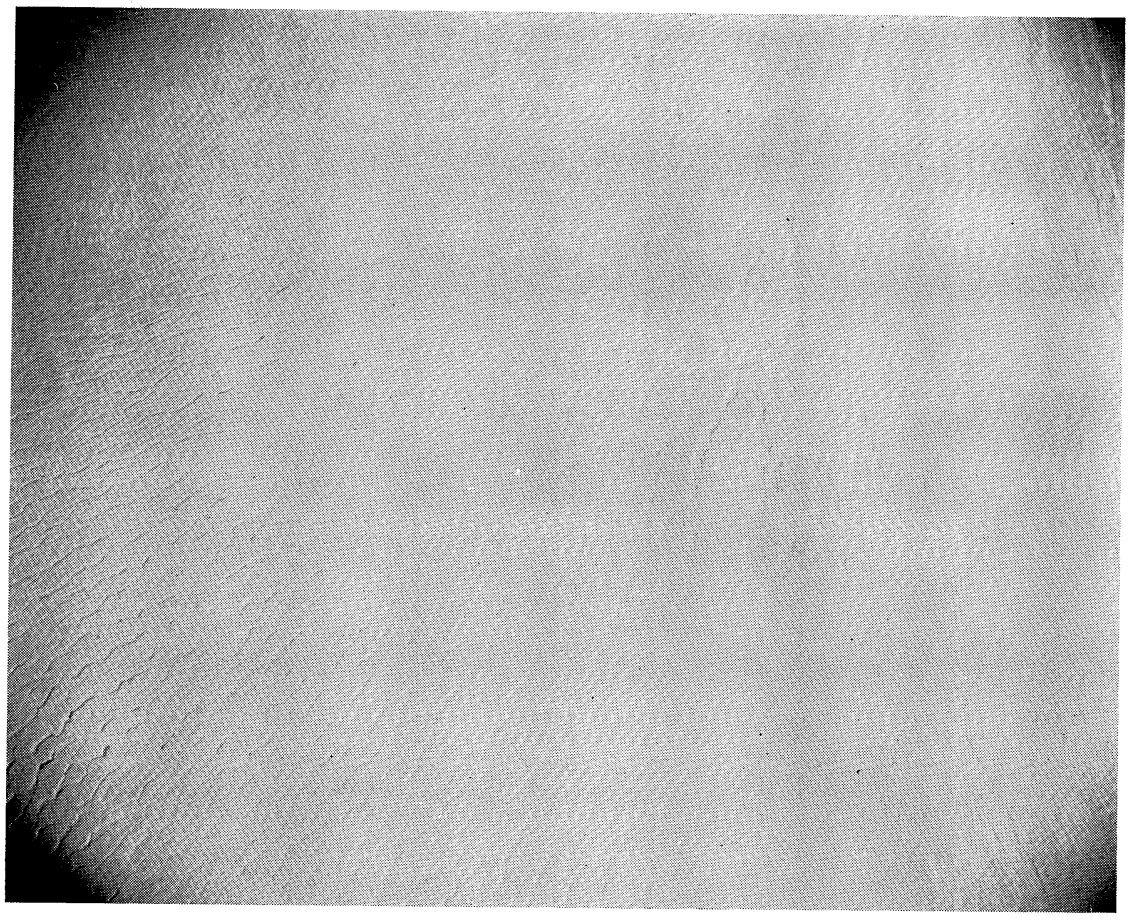

大陸承(縮尺約 20,000 分の 1 )

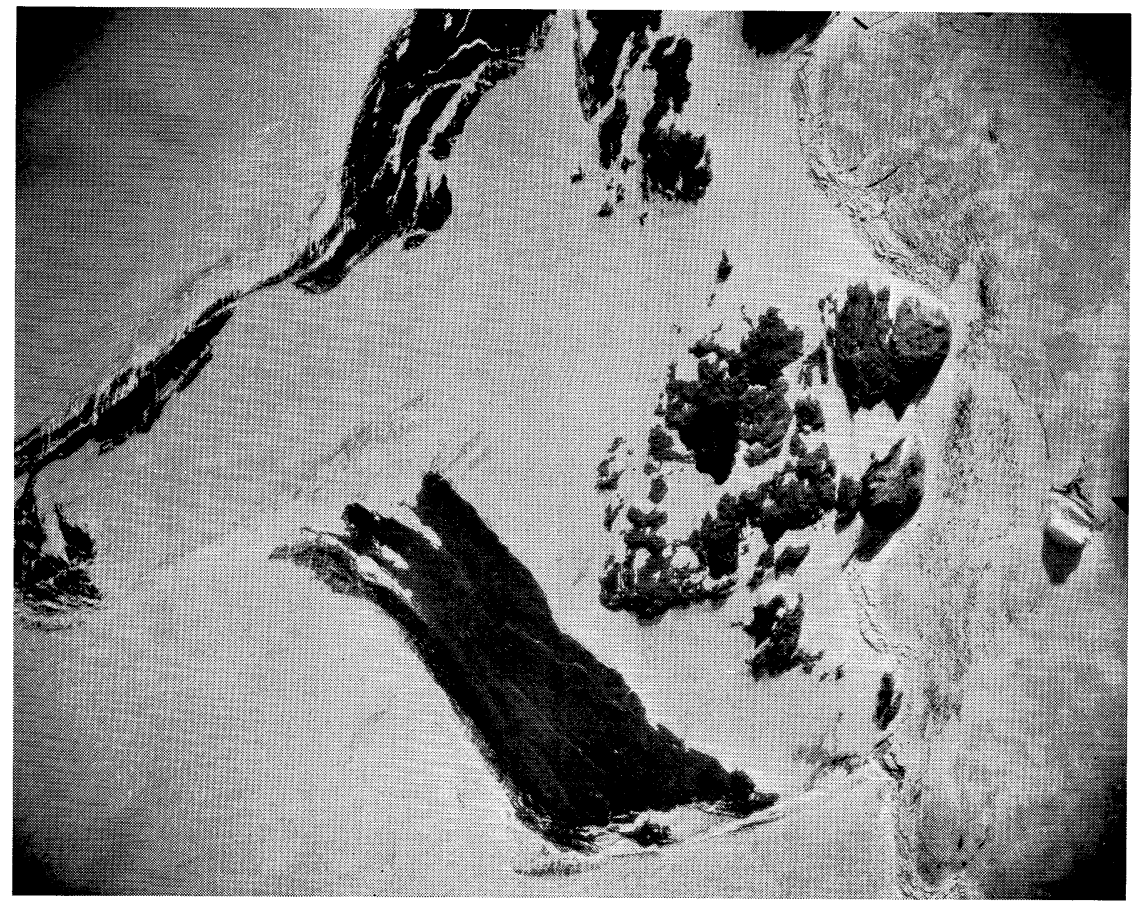

プリンスオラフ海岸露岩とモレーン（縮尺 約 24,000 分の 1$)$ 
この場合，セスナ 180 で極地用に各種計器をつけ，さらに重い空中写真機をつけることは甚だ困難であ つたが，一応水上機の場合にはウイリアムッン F 24 空中写真機で斜写真を，フェアチヤイルド K $17 \mathrm{C}$ による璱直写真はフロートをスキーにつけかえた時のみ行うということにして，カメラホールとファイン ダーホールを作つた。

一方，乗員の訓練も，パイパースーパーカブ機を使用して，霞ケ浦の土浦で行われた。

このように, 水上機に習熟する一方, フロートの到着を待つて「さち風」の改装注っり, 出発前に撮影 試験飛行を行うようにと急いだのであるが，準備がまにあわず，遂にたざ 1 回の F 24 による斜写真撮影 を行つ炕げけで出発することになつた。この他に, 飛行機自体としてる, また航法上るいろいろの試験飛 行を計䤄していたのであるが，結局は時間がなく，準備不足のま〉11月になり，飛行機は分解，棝包して 宗谷飞積込んだ。この積込みの方法についてもいろいろと案がでたのであるが，結局翼・胴体・フロート を分解・相包して前部甲板左側に積込むことに決定したのである。

この上らと飛行機の選択が行われているのと平行して地図作成用機材の準備に着手した。

機材準備にあたつて考光た条件としては, 僅か 2 人の人員で行わなくてはならず，また極地という悪条 件のもにに行らのであるから，すべての器材をできるだけ軽く小型にしたいといらことである。しかる， 低温でも完全に作動し操作が簡単なものでなくてはならない。一方出発がせまつて抽り, 短期間に準備し なくてはならないので，なるべく既存のものに必要な処置を行つてもつて行くことにした。携行品の主な ものは佽のと叔りである。

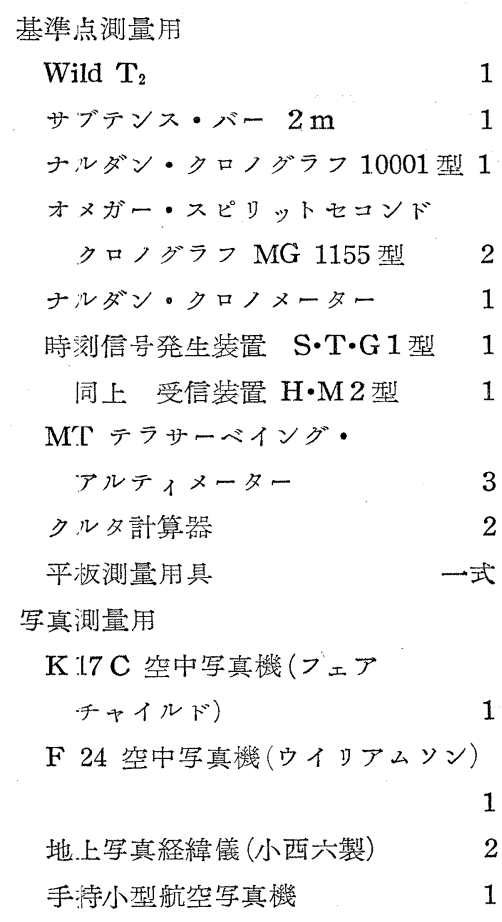

1

\section{南極携行主要機材表}

1

(1)

.

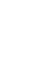

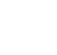

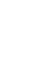

1

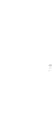


写真測量用としての写真機の決定は, 飛行機と重大な関係があり, 飛行機の決定までなかなか決められ なかつたが， 7 月末に漸く飛行機はセスナ 180 を使用することにきまつた。しかし前述のセスナ 180 の性 能表の如く, どうも積載能力が足りないので, できるだけ軽量であることが要求され，3 カ月で入手可能 といら点からフェアチヤイルド K $17 \mathrm{C}$ が撰ばれた。さらに, 斜写真用として, また場合によつては垂直 撮影用としてウイリアムソン F 24 も携行することにした。南極のような未知の土地で，しかも，小さな 飛行機で空中撮影を行了場合に，垂直撮影を行了か，斜写真で行くかは，大分考えたのであるが，とにか く，飛行機の目的が，基地への道や，基地適地の発見にあることになると，やはり垂直写真が欲しいと思 い，垂直と斜の両方行えるようにしたのである。

この二つの写真機性能は次の通りである。

$$
\begin{aligned}
& \text { フェアチャイルド K } 17 \mathrm{C} \\
& \mathrm{f}=153 \mathrm{~mm} \text {, 画面の大きさ } 23 \mathrm{~cm} \times 23 \mathrm{~cm} \\
& \text { シャッター } 1 / 50,1 / 100,1 / 200,1 / 400,
\end{aligned}
$$

絞り $6.3,8,11,16,22$

ウイリアムソン F 24

$\mathrm{f}=125 \mathrm{~mm}$ 画面の大きさ $124 \mathrm{~mm} \times 125 \mathrm{~mm}$

シャッター $1 / 300,1 / 400,1 / 450,1 / 500$

絞り $4,5.6,8,11$

このカメラを撰ぶにあたつて，広角を考皃たのは，なるべく広い範囲をとろうと思うので当然であるが $\mathrm{F} 24$ は, $f=3^{1} / 4$ インチは時間的に間に合わず, 5 インチにした。るともと斜写真は, 垂直写真の補足で あり，また重直写真では被えないところの作図に用いることにあり，写真機自体としては測量用として充 分なものとは考光なかつたので5インチでがあんすることにした。

次に写真処理の問題であるが，これは撮影済の写真はできるだけ早く完成して，次の計画への参考資料 に使いたいので船内で焼付けまで完了することが望ましい。しかし，せまい船内でこの処理を行い，乙か あ水が非常に不自由なのであるから，出発前にすで調合したものを持つて行き，現地では水に溶かせば よいという方法を取り，すべて D 76 で現像を行い，印画紙はコニトーンを使うことにした。今までの文 献では D76 を主とし，状況によつて他の現像液を使つている国もあるが，こちらは D76 のみで行い， 念のため増感現像剤として，コニドールスーパーも若干用意した。印画紙も，すべて $24 \mathrm{~cm} \times 25 \mathrm{~cm}, 13.5$ $\mathrm{cm} \times 13.5 \mathrm{~cm}$ とフイルムに合わせて切つたものを持参した。これは人員不足の船上の焼付にできるだけ 手数をはぶこうと考元からである。

\section{III. 南極における撮影飛行}

11 月 8 日東京発, シンガポールに向つて南下した。11月15日フィリッピン沖についた頃台風にあい, 16 日まで船は大いにゆれた。このため，前部甲板につんであつた飛行機の梱包が壊われ，機体に損簐を受 けた。波がしずまつてから調べたところによると，荷物室後壁の円框から尾端の円框をで本が曲り，交換 を要するようであり，外板る大分なおさねばならない状況である。

シンガポール入港中，シンガポールの技術者の応援を得て修理にかつり，結局前記の箇所のほか L型ア ングルの交換，リベット交換等を行い，外板や風防の修理も行つた。

整備の人々の努力により，5日間の大港期閒中で修理完了し，再梱包した。12月19日, ケープタウン 大港，20日から 23 日にわたつてセスナを開梱，エンヂンの試運転を行い，再び梱包して，12月29日ケ ープタウン出港, 南極大陸へ向つた。 


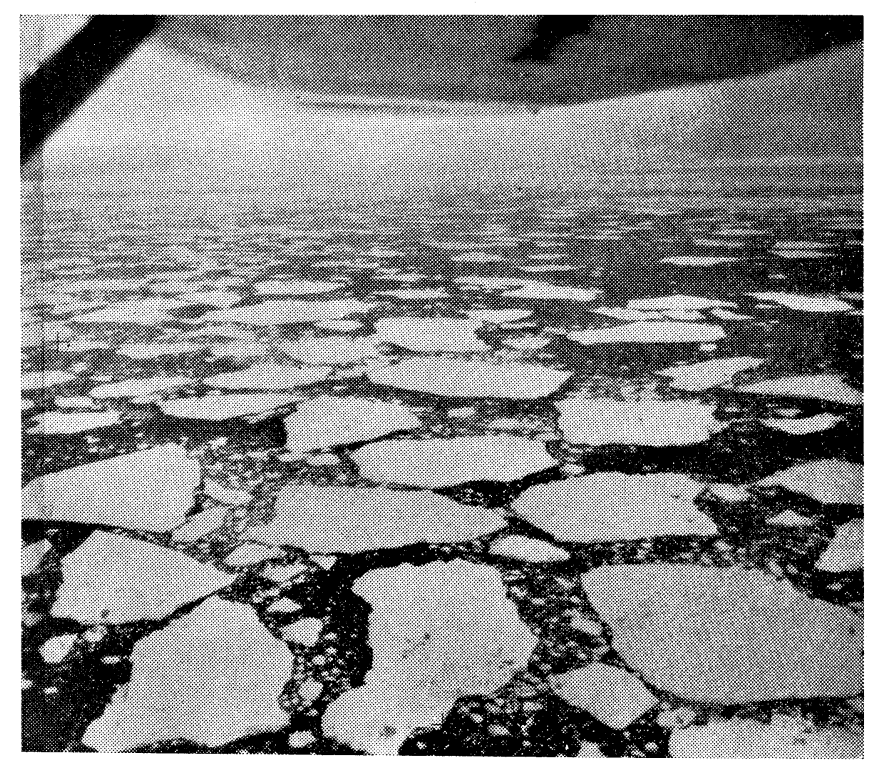

写真 2 クック岬沖のパックアイス

1957 年 1 月 7 日, エンダービ沖に到着，その後パックアイスの外縁に沿つて西進してクック岬1 方面へ 向つた。途中 $66^{\circ} 13^{\prime} \mathrm{S}, 42^{\circ} 04^{\prime} \mathrm{E}$ の地点で海鷹丸より燃料を受取つた。

エンダービ沖に達した時に，エンがービ西岸の偵察撮影を行いたかつたのであるが，まだ飛行機の組立 てが開始されてお括らず,どうすることもできなかつた。

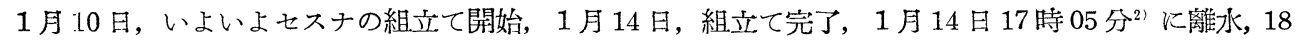
時 25 分, 1 時間 20 分の試験飛行を終兄て無事着水した。幸いと天気は上いのでクック岬の偵察撮影を行 らとのにと, 試験撮影のつもりで, F 24 をるつて飛行機にのる。パックアイスを越えて約 30 分でシェル フアイ次の末端に達する。 $20 \mathrm{~m}$ から $30 \mathrm{~m}$ の水崖がずつと続き，やがて明瞭な水崖がなくなりゆるやか

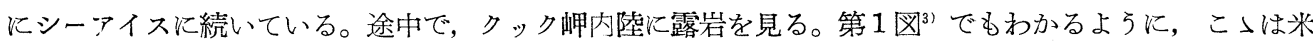
国 68 機動部陵が相当多くの写真をとつたところであり，この時の露岩も，米軍の写真にあつたのと同一の ものと思わ和る。

22 時 05 分着水, 2 時間 10 分にわたる最初の撮影飛行を終光て宗谷に帰る。直ちに現像 D 76 にて 20 分, 結果は兒かつたが, この時は始めてでもあり, 試駼撮影という意味も多分にもつていたので, 測量用の写 真としては，F 24 で斜に撮り，しかも手動で行つたために正確な方向を示さず，甚だ不満足なるのとなつ た。

この時は, さらにもら一度または二度三度と撮影を行いたいと思い, 米軍の写真も利用して地上基準点

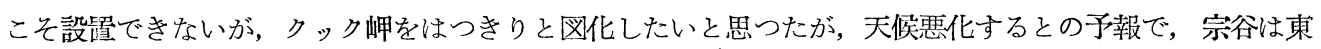
に進んだため, こ〉はこの一回の偵察飛行で終つてしまらた。

この飛行を第1回として次の表の如く9回の撮影飛行を行つたのであるが,さち風はこの他にも, 陵長 や船長等の偵察に約 10 回延 16 時間使用された。

1）クツク岬は現在地図ではりーザー・ラルセン本島とされているものが多いが, 今回はクック岬と呼んでけたので本文ではこの名称を使つ 生。

2) 時間はすべて東経 45 度の経带時を用いてある。

3この因の経緯度は，今回の観測結果が完全に整理されていないために既刊の地困を用いた。 


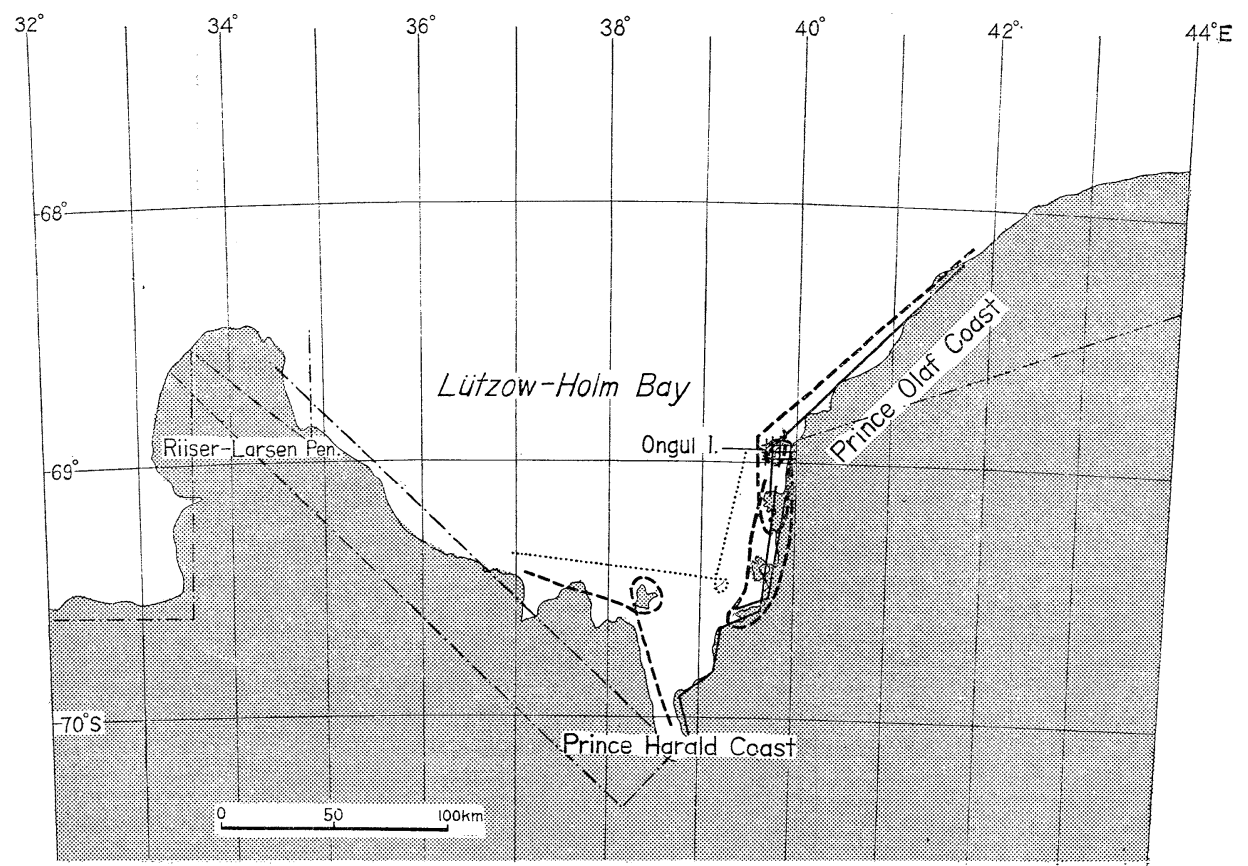

LEGEND

\begin{tabular}{|c|c|c|c|c|c|c|c|}
\hline Date & $n$ & & & & & & \\
\hline 195 & & & & Dat & & & \\
\hline & & & & $46-1947$ & 68 & -.- - - & \\
\hline 1957 & J. A. R.E. & & Oblique F24 & $1936-1937$ & $\begin{array}{l}\text { Christensen } \\
6 \text { th Expedition }\end{array}$ & & Oblique.R.M.KP $2 / 1$ \\
\hline
\end{tabular}

第

図

セスナ 180 型撮影飛行記錄

JA 3059 さち風

\begin{tabular}{|c|c|c|c|c|c|c|c|c|c|c|}
\hline 回数 & 月 & 時間 & 操 & 縦 & 機 & 関 & 撮 & 影 & 飛行洔間 & 発 位 置 \\
\hline 1 & 1.14 & $19.55 \sim 22.05$ & 佐 & 藤 & 森 & 松 & 銀 & 治 & 2 時閶10分 & $\begin{array}{l}\text { S } 67^{\circ} 55^{\prime} \\
\text { E } 34^{\circ} 50^{\prime}\end{array}$ \\
\hline 2 & $1.16 \sim 1.17$ & $22.00 \sim 01.20$ & 佐 & 藤 & 森 & 松 & 鉣 & 治 & 3.20 & $\begin{array}{l}\text { S } 67^{\circ} 21^{\prime} \\
\text { E } 40^{\circ} 20^{\prime}\end{array}$ \\
\hline 3 & 1.18 & $12.55 \sim 16.10$ & 佐 & 藤 & 森 & 松 & 鋸 & 冶 & 3.15 & $\begin{array}{l}\text { S } 68^{\circ} 02^{\prime} \\
\text { E } 40^{\circ} 27^{\prime}\end{array}$ \\
\hline 4 & 1.26 & $19.00 \sim 21.20$ & 佐 & 藤 & 前 & 田 & 錩 & 冶 & 2.20 & $\begin{array}{l}\text { S } 69^{\circ} 02^{\prime} \\
\text { E } 39^{\circ} 10^{\prime}\end{array}$ \\
\hline 5 & 1.27 & $11.06 \sim 13.51$ & 佐 & 藤 & 前 & 国 & 鋸 & 治 & 245 & " \\
\hline 6 & 1.30 & $19.38 \sim 21.08$ & 佐 & 藤 & 前 & 是 & 銀 & 治 & 1.30 & " \\
\hline 7 & 1.31 & $13.08 \sim 14.58$ & 佐 & 藤 & 森 & 松 & 鈮 & 治 & 1.50 & "I \\
\hline 8 & 1.31 & $17.59 \sim 19.49$ & 佐 & 藤 & 森 & 松 & 鋠 & 治 & 1.50 & " \\
\hline 9 & 2.1 & $14.05 \sim 19.49$ & 佐 & 藤 & 森 & 松 & 鉣 & 治 & 2.55 & " \\
\hline
\end{tabular}

第 2 回の飛行は，プリンス・オラフ沖から行われた。この海岸については，今までほとんど知られてい なかつたのではないかと思う。米軍の飛行機は大陸内部を飛び，丁度その飛行の時は，雲があつたらし く,この海岸についての知識は全然なかつた。そこで是非撮影を行いたいと思つていたのである。1月 16 
日宗谷に積んできていた 2 台のヘリコプター(ベル $47 \mathrm{G})$ で水路偵察を行いながら進んでいたところ，パ ックアイス中にオープンシーを発見した。セスナの離水に充分可能なだけの広さがあるとのことで宗谷は そこへ向つて急いだ。急ぐといつてもパックアイスを割つて進むのでなかなか思うよう飞進まず，今日は 仕事なしと思つていたら，21時頃オープンシーに到着予定だから撮影飛行の準備せよとのこと, 20 時頃に は準備完了して宗谷がオープンシーに着くのを待つ。21時尒定通りオープンシーに着く。オープンシーは 大部狭くなつたらしい。第 1 回の離水は滑走距離が充分とれず失敗，2回目は無事離水，進路を $150^{\circ}$ に 取る。特間はすでに 22 時 00 分, 南極の夏の日は長いとはいえ光量は大分不足のよ5である。高度 $3000 \mathrm{ft}$, 速度 $100 \mathrm{mile} / \mathrm{h}$ で進む。この海岸もクック䖬同じく水崖で, シーアイスに接しているだろうとの想 をしていたのであるが， 22 時 40 分，前方に露岩が海岸線に浴つて並んでいるのが見㝋てきた。そして， 大垫水も氷崖をなして搞らず, 点々と並ぶ露岩で, 氷の流れ出すのをせきとめるよらな形で, だんだんと 急になる傾斜でシーアイスに続いている。

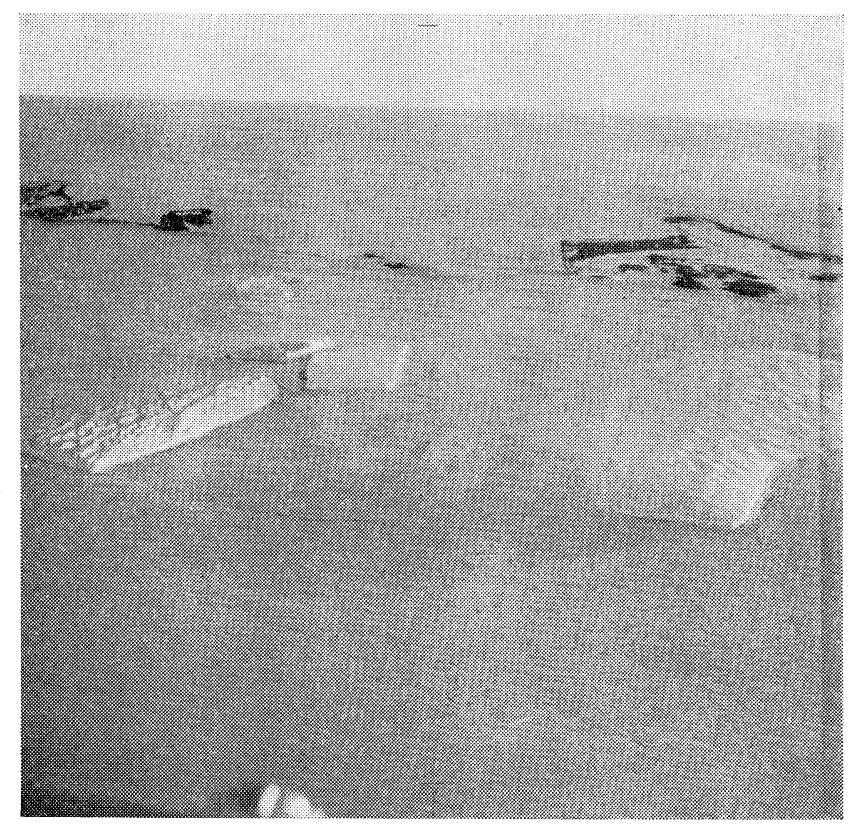

写真 3 プリンスオラフ海崖

この上うに思いがけない露岩の出現で, 海岸線を $\mathrm{f}: 4,1 / 300$ でシャッターを切りながら西進する。そ の5ちに, 左前方に岩山が見え出した。恐らくラングホヴデの山々だろうとは思うものの, ノルウェー隥 の写真は反対の西側から撮つたものなので，はつきりした結論は下せない。酉側に迴つてみることにす る。西側から見れば，確かに写真でみなれたラングホヴデの山々である。フイルムが殆んどなくなつてい るので，こ〉を一迴りしてまつすぐに船に向う。途中氷の状況を見ながら㷌船した。ところが船の附近の パックアイスの変化が激しく,オープンシーは大分狭くなつている。殆んど着水距離ぎりぎりである。17 日 01 時: 20 分着水, 直ちに現像にとりか〉る。南極の夏の日は長いとはいえ，日没後の薄明の撮影である。 D 76 2 倍の濃度にして，40 分現像，充分役に立つ写真ができた。

1月18日, 再び偵察飛行に出発，今度は光量も充分な時間である。昨日見つけた水路を更に確実にす るために, オラフ海岸から約 $30 \mathrm{~km}$ はなれたところのフアストアイスとパックアイスの境界にある水路 
上空を, 時にはその幅を測定しながら飛ぶ。後にこの水路が利根川下流に似ていることから, 大利根り一 ドと呼んだりされたが，その名にふさわしく幅は狭いところで $300 \mathrm{~m}$ ，広いところは $1,000 \mathrm{~m}$ 以上もお つた。そしてこの水路が海岸線から $26 \mathrm{~km}$ ないし $30 \mathrm{~km}$ のところを海岸線の形にリュツオホルム湾口 のオープンシーまで続いているのを磪認した。その後，プリンスハラルド海岸を，F 24 にて東西から撮影 して船に帰る。19 日午後，船はこのリードを進んだが，湾口のオープンシーに出る時は，流水にとざされ 難行した。僅か 1 日で流水が相当変化することがよくわかり，今後の偵察の場合は充分注意せねばならな いことだと思う。

1月 24 日，宗浴は最終地点に到着こっで荷下しを開始した。飛行機は直ちにフロートをスキーに交 換，26日から斜写真に代えて K 17 C による垂直写真撮影を開始する。

1月 26 日, 基地建設地と決定したオングル島, 宗谷閒の輸送路の垂直写真をコース撮影する。高度 $5,000 \mathrm{ft}$., 徒つて写真縮尺は 1 万分 1 である。これは直ちに現像, 燒付を行い, これをモザイクにして, 午後の雪上車偵察ならび輸送汇非常に役立つた。

このモザイク完成前に，或いは大ぞりで，まだリコプターで，一部は雪上車で地上から偵察を行つて いたのであるが，飛行機のように上から広範囲に見ることができないので方向をあやまつたり，場所を違 えたりして位置を確実知るのに苦心していた。たよ゙，この海氷は，はじめのうちは判読をあやまつて堅 い青水の上に雪がつもつたと判断していたのであるが，パドル(水中の水たまり)が，その状況は写真にも 示されているように，非常に多い。こ〉に雪上車が落ちると脱出に非常に苦労するので，これをできるだ けさけて通らなければならない。

この附近の主風は北東方向であり, 水山の北西側から南西側は雪の吹きだまりができていて割合にパド ルが少いことは写真を見ると明瞭でありこのような場所を写真上で調べて雪上車の進行方向を決定した。

1 月 27 日，再びオングル島特よびプリンスハラルド露岩地带東縁の撮影を行つた。すなわち, 今まで, ルウエーの写真では，わからない露岩地帯の東部の大陸水と接する部分の撮影を行つたわけであるが，こ の時は気流が悪く, 飛行機が前後左右に摇れとても撮影を続行できる状態でなかつたので，途中 $69^{\circ} 35^{\prime} \mathrm{S}$ $39^{\circ} 20^{\prime}$ の Hjartoy 島上空で引返した。この日は晴天ではあつたが，前述のように気流思く途中で撮影を 中止した。これが南極に技ける全飛行中唯一の天候障害であつた。

この 2 回の撮影は，もともとセスナに K 17 を積むのは大分無理をして扣り，カメラホールは全然余裕 のない大きさであつたのと, 全然試験撮影を行つていなかつたので, 写真機の位置高く, 周囲はけられて 測量用としては, 一寸不充分なものとなつた。これは，第1回の撮影で気がついたのであるが，連続して の偵察撮影のため,な扮す時間的余裕なく，そのま〉で，第 2 回の撮影を行つた。

1 月 30 日, 今度はカメラの位置を下げる工作も完了し, すでに 2 回の偵察撮影も終えているので, 明年 の本観測の計画用にオングル島の面積撮影を行い, 更に, 宗谷の東南方 $5 \mathrm{~km}$ にある新発見の島の撮影を 行5。オングル島はコース東酉に飛び，更に，念のために南北に 3 コース飛んだ。

1 月 31 日, この日は前々から狙つていたプリンスオラフ海岸の 海岸線の 垂直写真撮影を行5。13時過 ぎに出発，1時間ばかり海岸線に沿つて東へ飛んだが，カメラの具合恶く帰つて 18 時再び飛行する。今度 は高度 6,000ft にし, 㷌路撮影を行い, その屯〉南へ飛んでラングホヴデまで往復して, オングル島, ラングホヴデ北端を結んだ。このオラフの海岸は, 先にも述べたように, 海岸線の状況は今まではつきり しておらず，斜写真では 16 日の撮影で一応撮つたのであるが，これのみでは図化するのが面倒なので, 垂 直で海岸線に浴つて撮影したわけである。この写真と斜写真によつて, 未測の海岸約 $100 \mathrm{~km}$ が明らかに なる䈏である。この後のオングル島とラングホヴデ北端を往復撮影した。更にオングル島対岸の大陸海岸 線の南北の撮影も行つてオングル島附近の大陸の位置を確害に測れるよ5にしたかつたのであるが，東風 が強くなつて，飛行機が激しく流されるために中止した。 
2 F 1 日，昨日陵長より今後総員で輸送括よび建設にあたるとの命令があり，これが恐らく最後の撮影 になるかも知れないと思い，プリンスハラルド海岸を湾奥まで海岸沿いに垂直撮影を行い，その後，湾の 西南部の斜撮影を行つた。これはノルウエー榢の斜写真もあり，また湾奥からクック岬にかけて米軍のト リメトロゴンの写真もあるので, 一応オングル島からこの米軍の写真までつなぐつもりで行つた。K 17 と F 24 の 2 台の写真機を樍むのは飛行機の塔載量を考えると，ほとんど最大許容量に近く，また機内は それこそ足のふみ場もない位であつた。この時は, 先の露岸地带東部の写真は，一応途中まで撮つていた ので, 西部の海岸線に沿つて飛んだ。この 2 回の垂直撮影と偵察の時に撮つた斜写真とで, この露岩地带 の状沉をはつきりさせ，本観測の撮影計画に有力な資料とする計画だつたのである。この撮影で湾奥 $70^{\circ} \mathrm{S}$ まで大り，その後りュツオホルム湾西岸に沿つて，F 24 で斜撮影を行つて帰つた。

この撮影でもつて一時撮影飛行を中止して，基地建設执よび基準点測量にとりかっつたが，これはなか

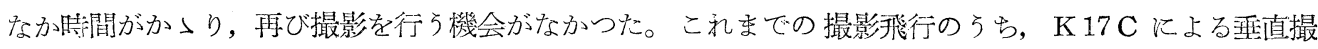
影は这中で写真機の調子悪くほとんど手動で行つたのであるが，写真は全然焲障なくとれた。

基準点测量

空中写真は，いろいろの点で危ぶまれながらも好天候に恵まれて何とか続けられたが，基準点測量もま た，いろいろの難問題を含んでいた。24日宗谷接岸と同時に，水上で器材の点検という意味もめつて天測 を行つたが，氷上ではセオドライトが固定せず，時に時間がか〉ると脚のところの氷が溶けて沙下し，測 定が行いがたく，結果は良くなかつた。

2 F 1 日，基地への輸送が始まるとともに印部隊員が 基地へ向い， 2 月 2 日建設予定地の南方 $200 \mathrm{~m}$ の丘の上で，太陽観測を開始した。その後，3日，4日と3 日間にわたり観測を行つた。観測は，垂值角 は延 30 対回, 方位角は 10 対回行つた。計算は 2 高度法によつてまず概略位置を求め, それから単高度法 で経䋽度の漸近阡算を行つた。

この時の時刻は, 宗谷通信室内の電気接点つきクロノメーターを, 各地の 報時信号中, 受信状況のよい もので較正し，これを時刻信号発生装置により発信し，現地の摼帯用小型受信機で受信した。

かくて, 天測点の緯度 $69^{\circ} 0^{\prime} 22^{\prime \prime} \mathrm{S} \pm 4^{\prime \prime}$, 経度 $39^{\circ} 35^{\prime} 24^{\prime \prime} \mathrm{E} \pm 12^{\prime \prime}$ 方位角は, 方位標に対して $100^{\circ} 18^{\prime} 12^{\prime \prime} \pm 7^{\prime \prime}$ 当得だ。

この後, この点の南の谷で, サブテンスバー $(2 \mathrm{~m})$ を用いて距離測定を行い, 2 区間で $235 \mathrm{~m} 71$ を得 た。

この二つの観測結果から，三角測量によつて，東オングル島の主なる丘の上を撰び，9点の基準点を設 置した。観測方法は，各点で 3 対回の観測を行い，また前方点として，大陸の露岩を4 カ所観測した。

高さは，東オングル島西南部の開水面を基準にして測つたのであるが，この附近の汀線の状況をみる と，0.5 m〜1 m 内外の海面の変化があるらしいので，験潮を行う必要があるようである。

これ等の基準点はいずれも露岩上に設け，天測点は岩に十学を刻んだのであるが，その他の点は時間な く、マジックインキで十学を描いたに過ぎない略式なるので復元困難ではないかと思われる。

この)基準点は，測定後いずれも空中写真に刺針して䚻国後の図化に用いた。

この他，国内への連絡用として 10 日，基地の 2 千分の 1 の平板測量を行つた。

また，刺針と同時に各基準点より，地上写真経緯儀で，周囲の撮影，特に大隋和よび西オングル島を主 としで, 実体写真撮影を行つた。これは, 帰国後の空中写真の図化に際し参考に用いる目的, 時に高さの 点検に:用いる予定で行つたものである。 


\section{IV. 調査地域の概況}

東はプリンスオラフ海岸 $41^{\circ} 40^{\prime} \mathrm{E}$ より, 西は $34^{\circ} \mathrm{E}$ のクック岬までの海岸線中 $35^{\circ} \mathrm{E}$ より $37^{\circ} \mathrm{E}$ に至 るクック岬東岸の西北より東南へ走る約 $100 \mathrm{~km}$ の海岸線の部分を除き，約 $300 \mathrm{~km}$ の海岸線の撮影を行 つた。

この地域の東部プリンスオラフ海岸は，先にも述べた如く，今までは様子がよく知られていなかつた が, 海岸線はあたかも大陸氷をせきとめる如く, 露岸が点々と並び, 海岸線はあまり激しい出入がなく, 割合に単調な形である。この海岸線の形をそのまっに，定着水が $30 \mathrm{~km} ５ 0 \mathrm{~km}$ 続きその北方にパック アイスが $100 \mathrm{~km}$ 以上も全般に北行くに従つて密度が小さくなつて続いている。

大陸氷はゆるやかに内陸淌向つて高くなり，2,000 m の高度で飛行したのであるが，内陸には，露岩， 或いは山脈は全然みられなかつた。海岸線より内陸へ $200 \mathrm{~km}$ までには大きな山脈または露岩は氷上には 出ていないものと思われる。

一方，この大陸水が海岸の定着水に変るところはだんだんと傾斜が急になつているが，クック岬のよう に氷崖をなしていない。そして露岩を囲むように小さな水河となつて海落ちているところるあり，氷山 が多い。しかもこ〉の海岸の水山は，大陸より押出されて来る途中，海岸線附近の露岩地带をのりこえる 時の歪で, 氷に格子状の割目ができ, これがその杰入大陸水とはなれて氷山になるためか, 或いは別の原 因かはつきりしないが写真のような水山が多い。全体としてはテーブル状なのであるが，それよりも，平 板を雨端をるつて曲げ割目が大つた形といつた方が良いかも知机ない。しかもこの割目が比較的規則正し い形を示しているのは, 何か原因があるのだろらと思われるが, 未だその原因についてははつきりしたこ とがわからない。

この海岸は, 別に比較する写真もないので本観測で更に多くの写真をとり，できれば，エンダービラン ド $\left(55^{\circ} \mathrm{E} 66^{\circ} \mathrm{S}\right)$ まで $700 \mathrm{~km}$ を結びたいものである。

次にノルウエーですでに 25 万分の 1 の地図のできているリュシオウ・ホルム湾岸であるが，この海岸は F 24 による斜写真でほよ゙, ノルウェー栵の写真と同じところを撮影した。更に東岸は, 垂直で 2 コース, および斜で大陸側より撮影したのであるが，20 年前の 2 月と，1957 年の 1 月末と比較してみると，今回は 水の状況が若干変つているのに気がつく。そのもつとも顕著なのはホノールブリュツガの 水舌が殆んどな くなり両側の露岩を結ぶ線まで海岸線が後退していることである。この傾向は他の水舌でも若干見られ る。

しかし, これでもつて最近の大陸氷の後退, 南極の暖化説に直接結びつけるのは疑問であるが, 注目す べき現象の一つで，これが今年だけのものか，或いは来年もまた同様であるか，本観測の 撮影は是非行つ てみたいるのである。

・露岩地带については特に述べることはないが, たざこの地域の露岩地帯, いや大陸水を含めて, 非常に 湖沼が多いということである。

ノルウエーの地図は, 細部では若干のまちがいがあるとはい光, 非常に良くできている。たしかに今回 の観测と緯度では約 $2^{\prime}$ ，経度は約 $10^{\prime}$ 違つてはいるが，これは地上基準点を設けないで作つたものとして は仕方がないものといえよう。

この他，斜写真で龱化したために，写真上で，島と岬を見あやまつたり，また，二つの島，或いはとれ 以上三つの島を一つにしたりしたところはあるが，いずれる小さなあやまりであり，また沖合の小島は， 斜写真で一方の側だけ撮つたために，写真にうつらなくて，困化されていないという点もあつたが，これ む避けられないあやまりであろう。

次に海水であるが，1月中旬には， $69^{\circ} \mathrm{S} 39^{\circ} 20^{\prime} \mathrm{E}$ 附近は写真にみられるように 4 種類の 定着水に 被わ 
南極に扣ける空中写真測量 (鐉治晃三)

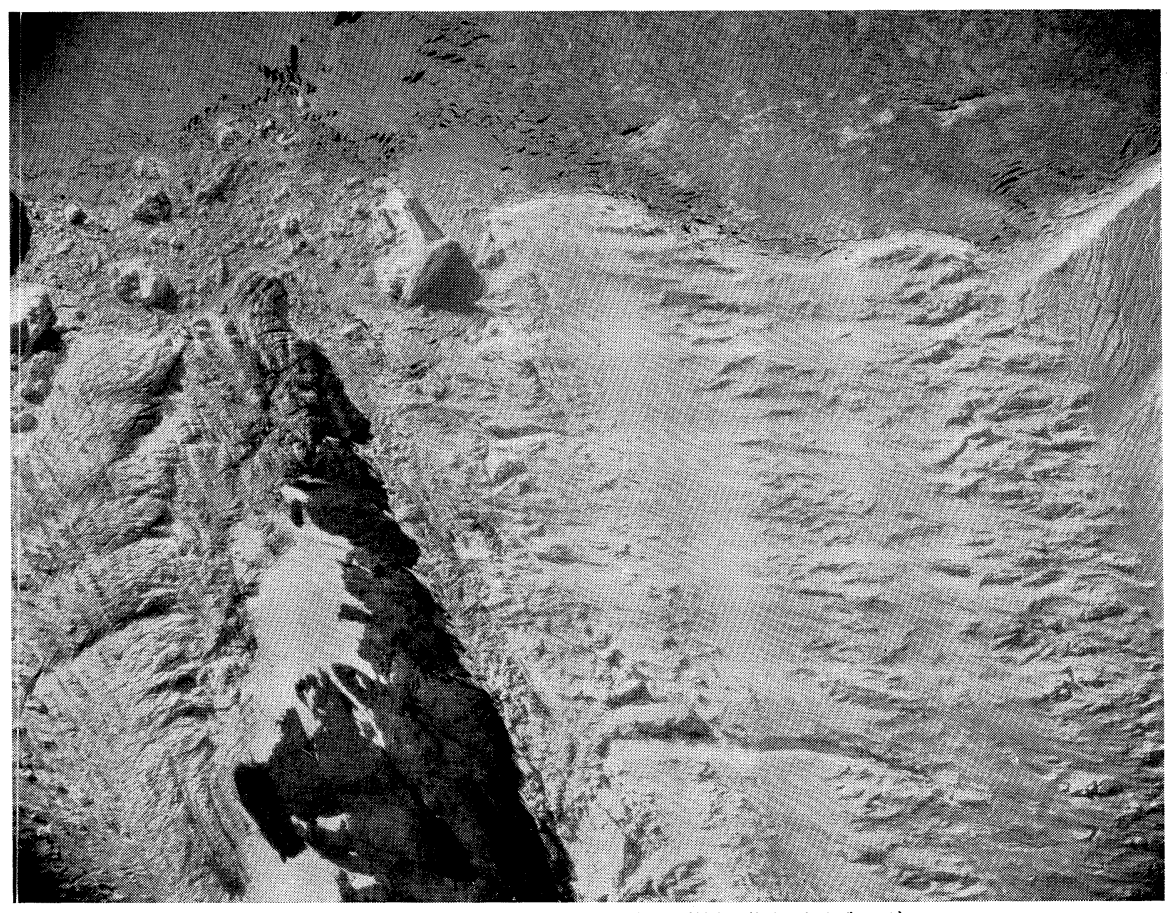

プリンスオラフ海岸承河と露岩（縮尺約 24,000 分の1）

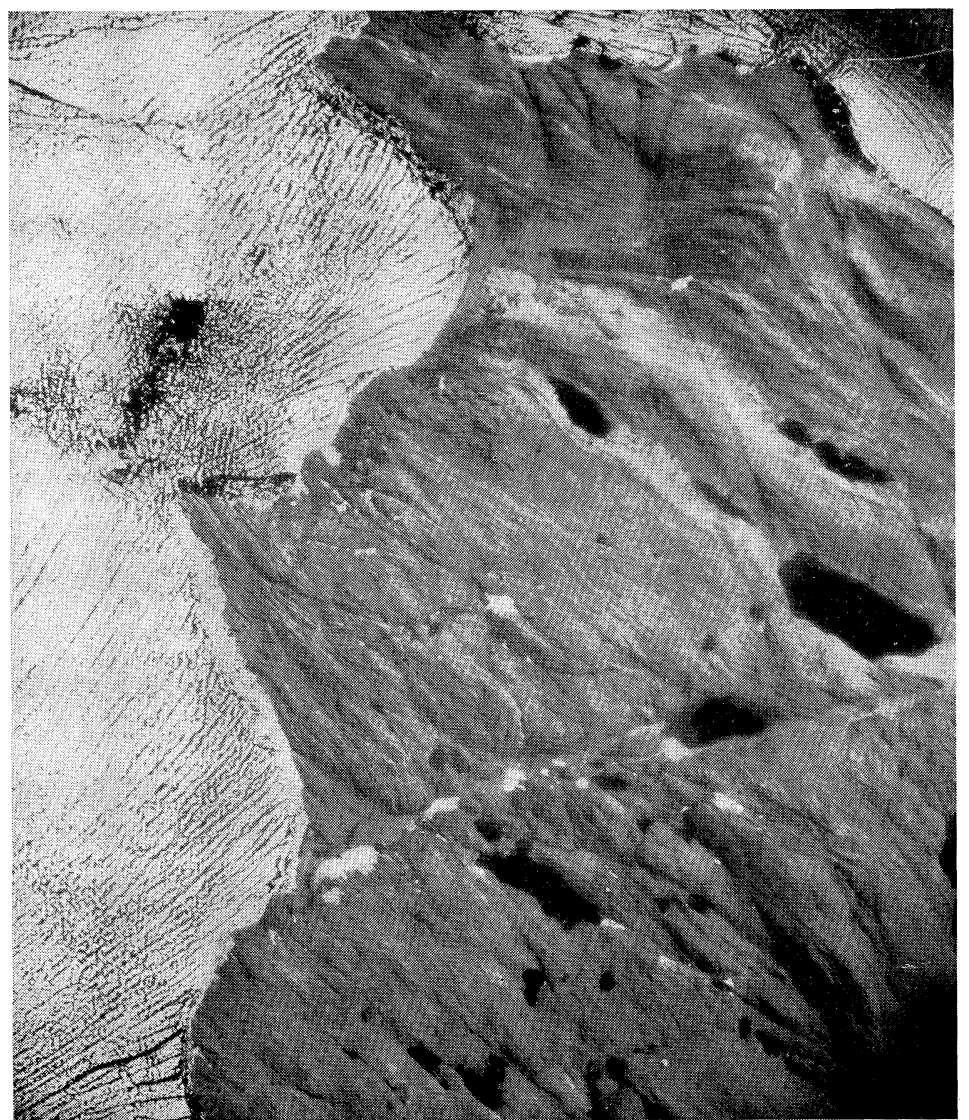

リエツオホルム湾東岩の露岩 縮尺約 1 万分の $139^{\circ} 40^{\prime} \mathrm{E} \quad 69^{\circ} 28^{\prime} \mathrm{S}$ 附近で露岩上の 黒いところは湖沼である（縮尺 約 22,000 分の1） 


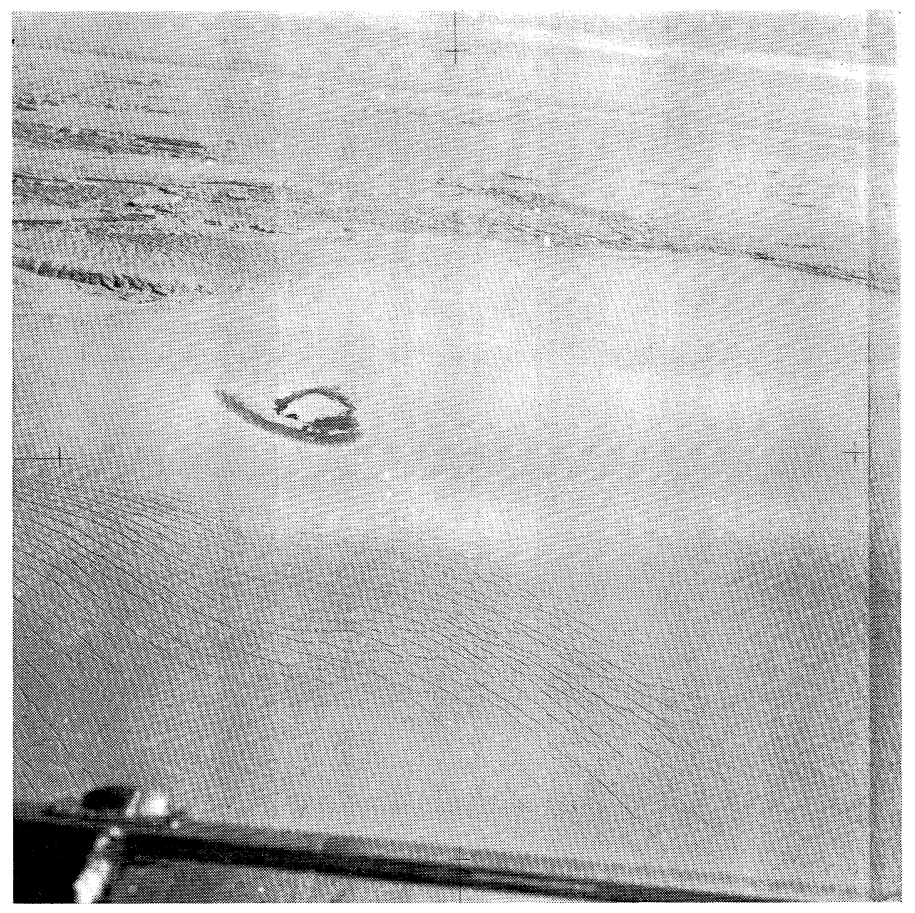

大陵氷上の湖水

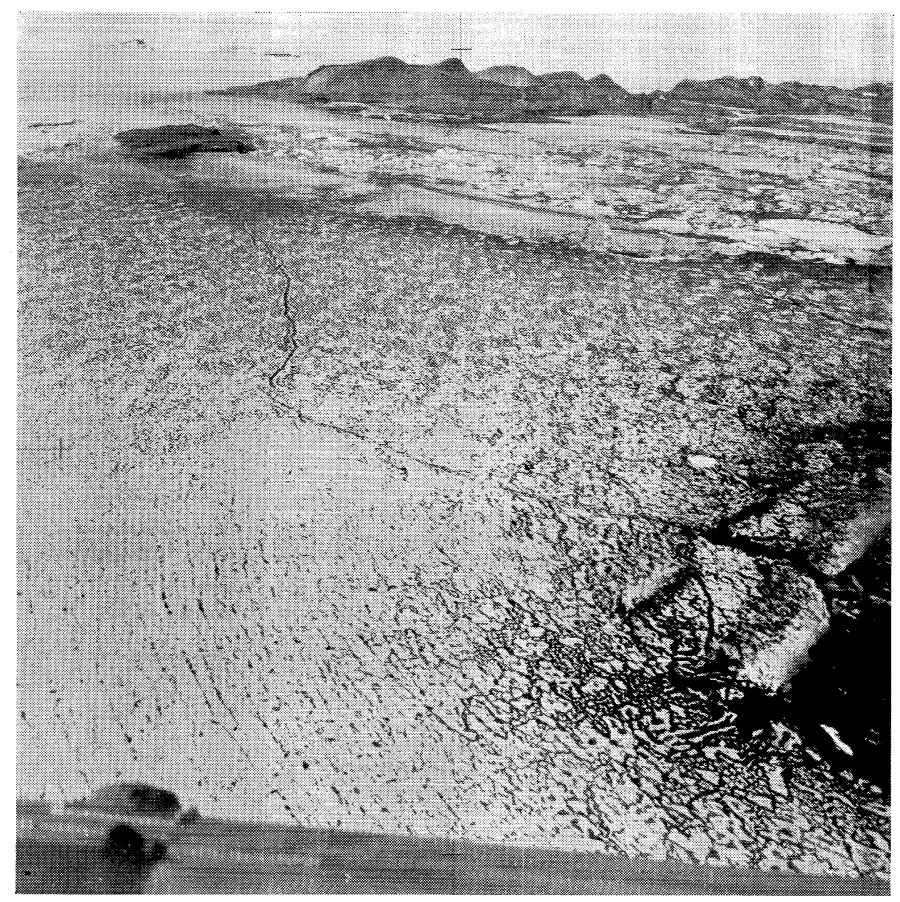

ラングホヴデ附近海水はパックアイスをなつている

$-58-$ 


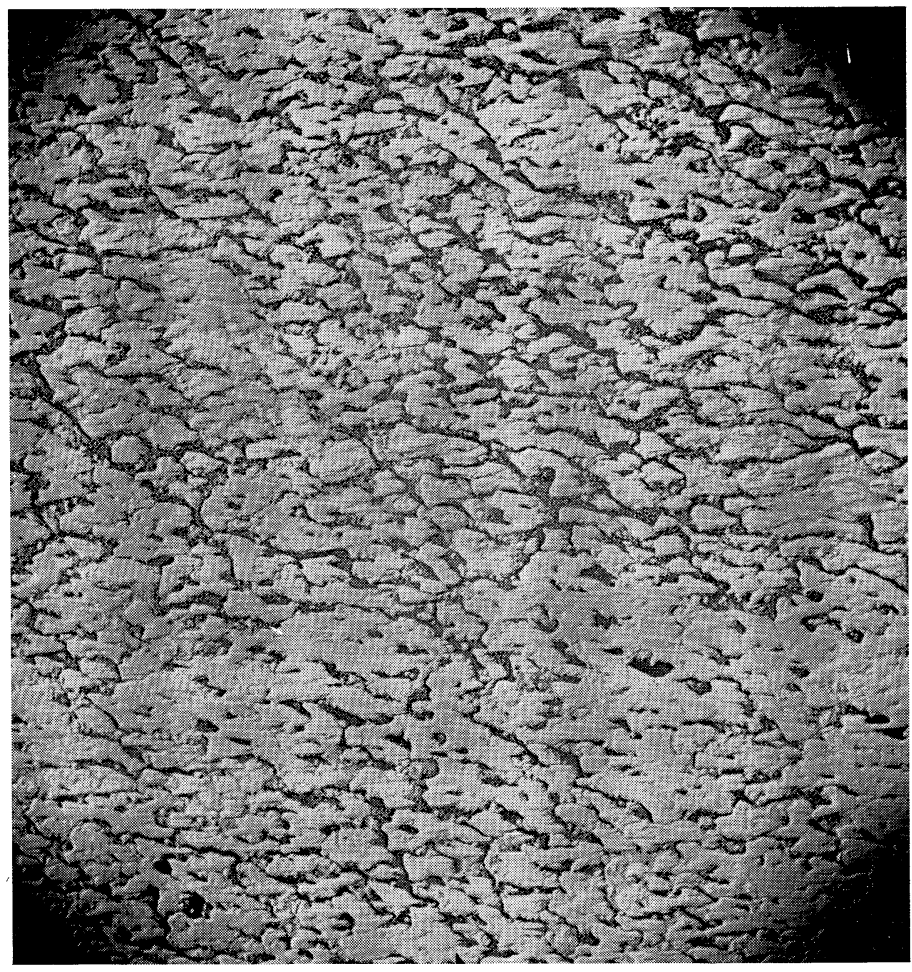

写真 4 パドル 黑灰色のところがパドルであろ（縮尺 約 7000 分の 1)

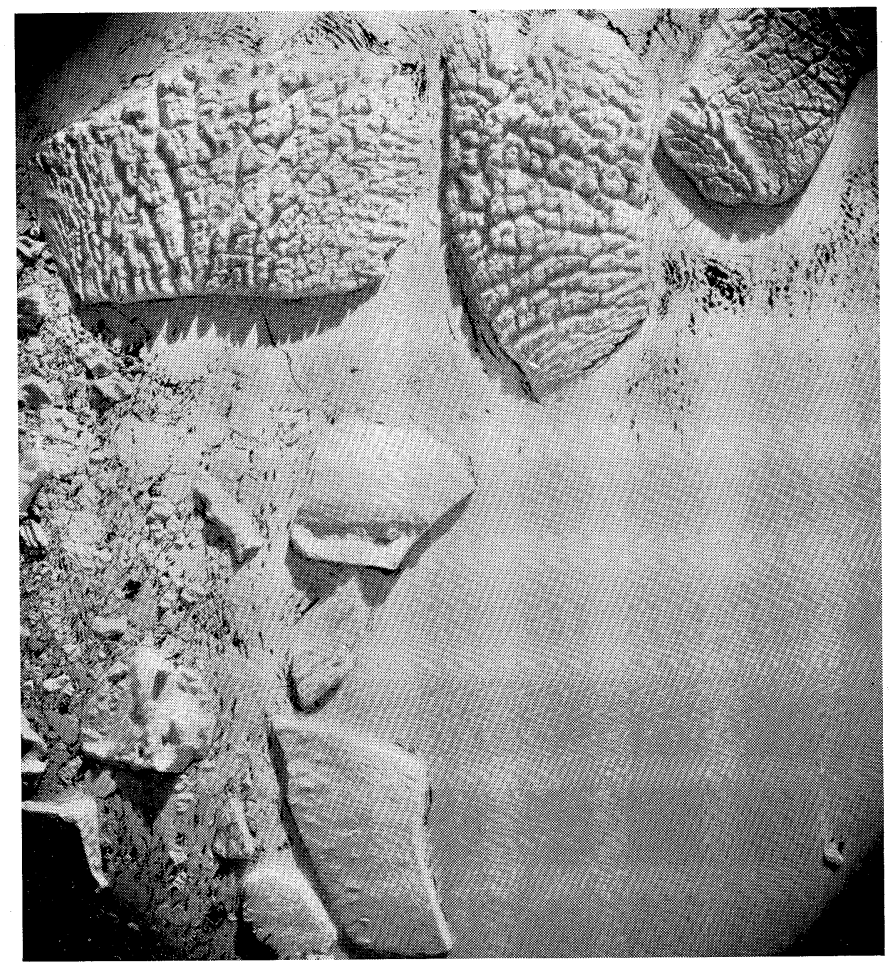

写真 5 格子状の亀裂の入つた氷山（縮尺 約 28,000 分の 1） 


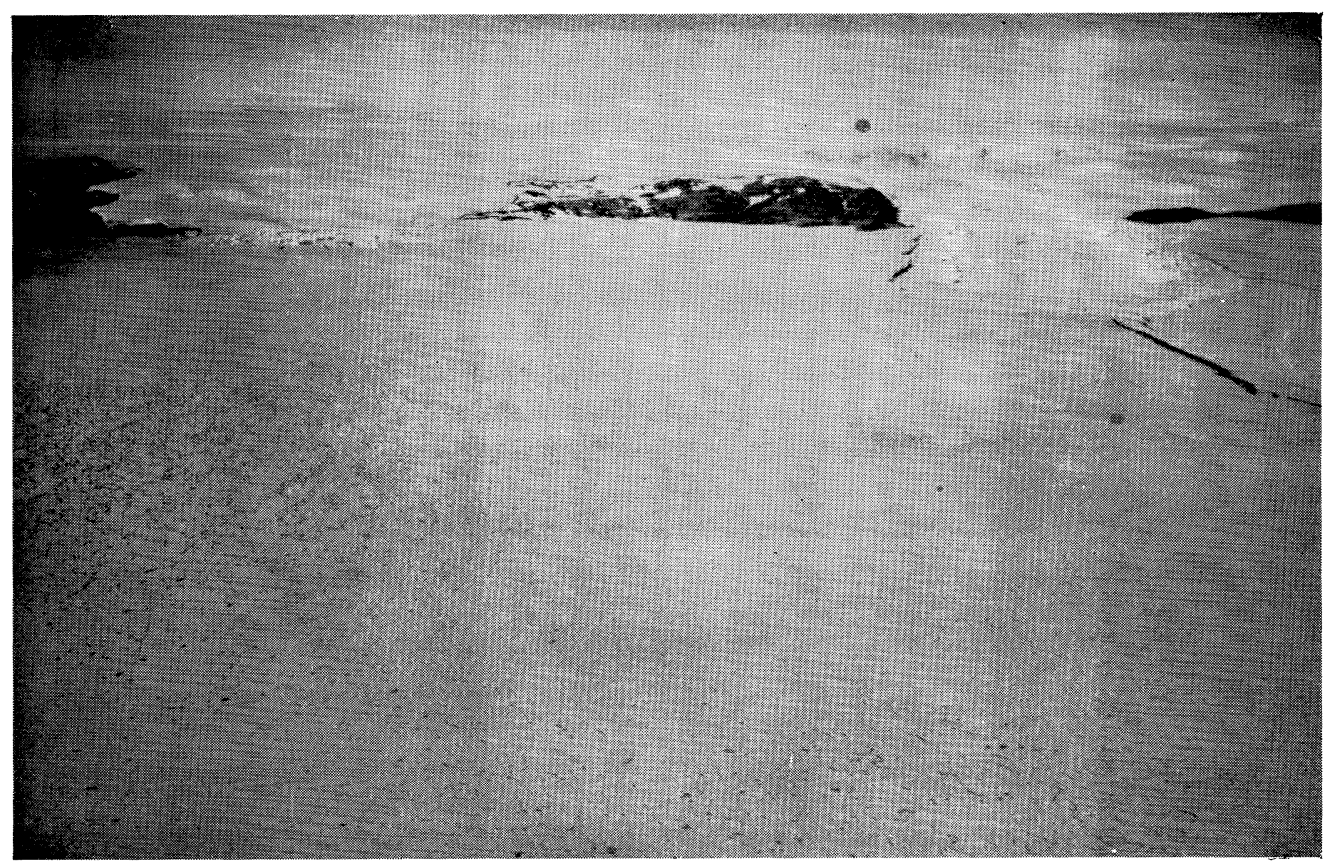

写真 6 ノルゥェー豚の撮影した氷舌の写真 (1957)

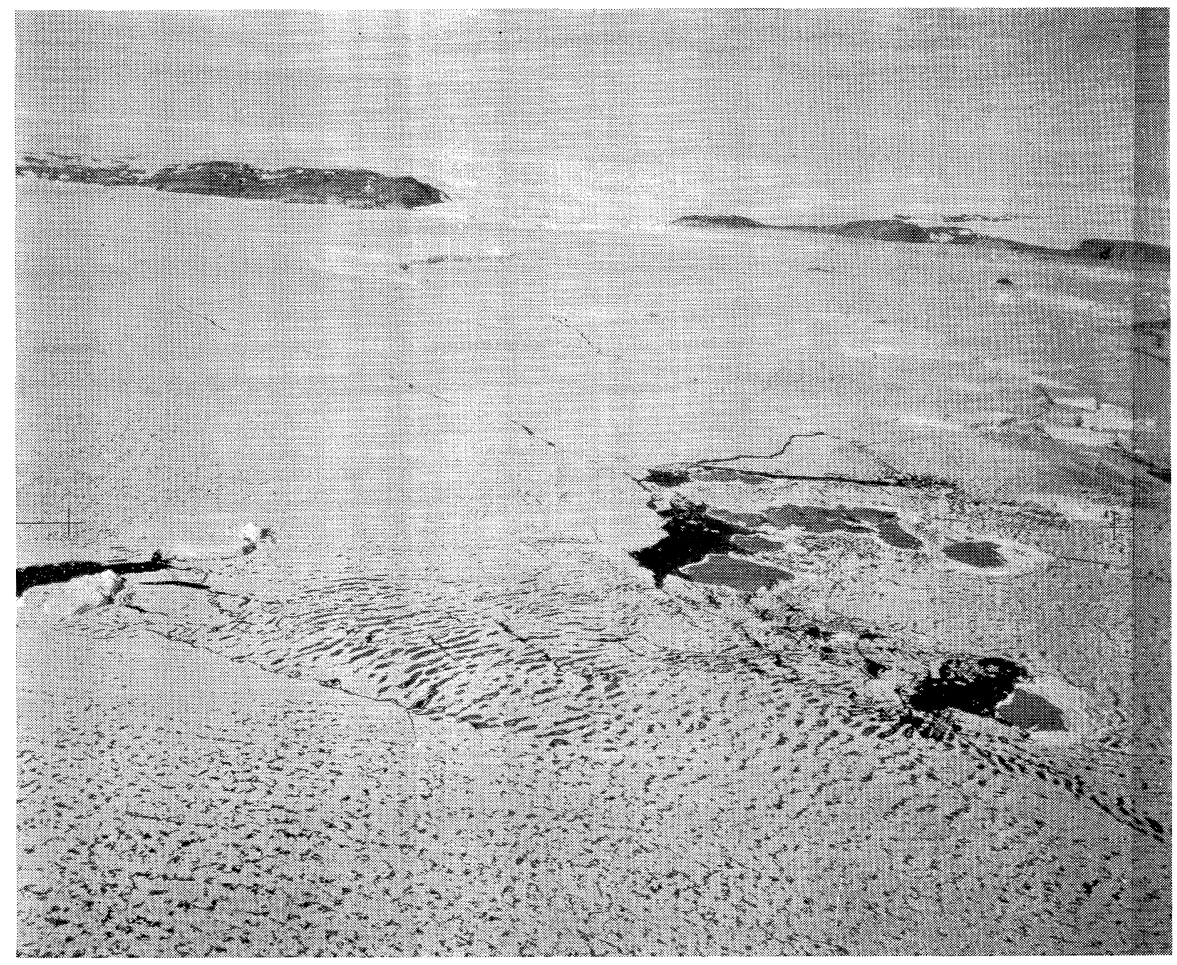

写真 7 予備観湖で撮影した写真 6 上同じ場所の写真 水舌が非常に少くなつている。(1957) 


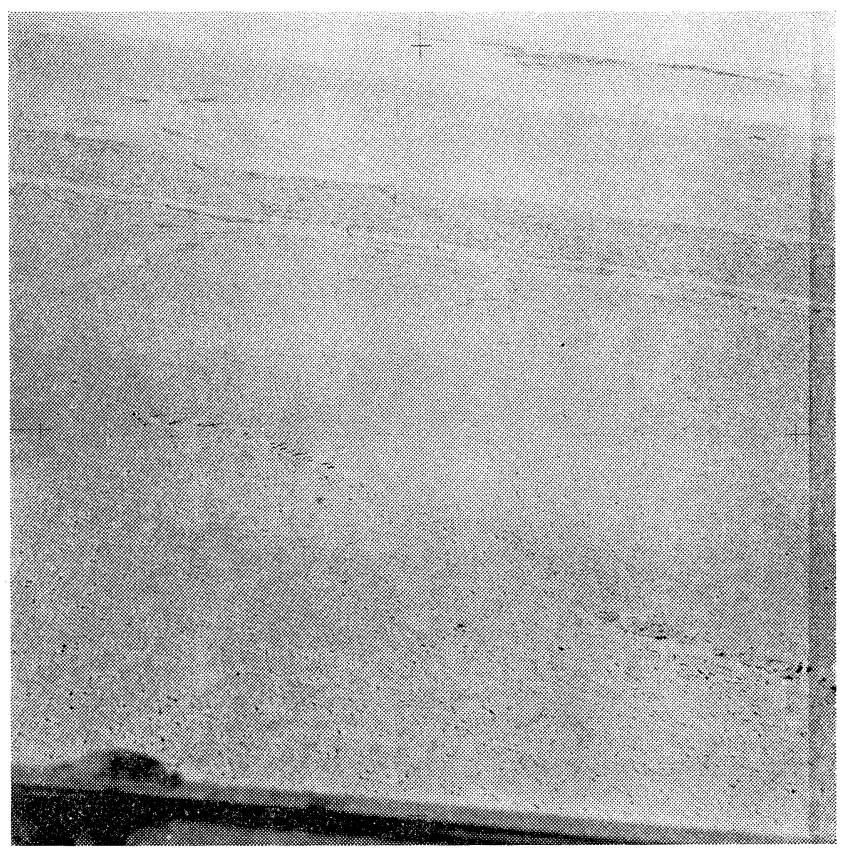

写真 81 月 16 日攝影のオングル島西方の海水の状況右上方の黑にところはオングル島

れていたが，これがだんだんと沖合からとけて，接岸中に写真手前の 2 種類がなくなつてオープンシーと なり，その後，越冬陵の報告によれば，第 3 番目の水をで溶けた様子である。

この定着水はパドルが写真のようと点在し，輸送にはをことに障害を与えた。このパドルも写真上では 二種類判読され，割合に形がはつきりと黒く写るのは深さも深く，縁が垂直になつているものであり，写 真上でその一つ一つのパドルの縁の線がはつきりしないのは, パドルが比較的浅くゆるやかになつている ものである。これは，前者は非常に輸送の障害になり，後者はそれほどでもなかつた。

まだングホヴデの海岸線近く, 或いは散在する島の南西側はオープンシー, またはパックアイス地帯 となつているが，ノルウェーの写真ではこれほぼ水面が出ていない。同じ時期, 否, 今度の場合はかえつ て少し早いにもか〉わらず，このよ５亿広い水面があることは，先の水舌の消滅と共に，今年だけのこと か，またはだんだんとこのようになつているのか興味のある問題である。しかし湾奥のバッダ島附近は～ ルウェーの写真と殆んど同じようにみられ，リードの状況も寒に良く似ているょうに思觉る。

次に.クック岬であるが，これは，1947 年の米軍の写真が詳しく，今回は僅かに一度の飛行のみであつた ため, しかも第 1 回の飛行であまり状況ははつきりしなかつたが, 岬の北端は $20 〜 40 \mathrm{~m}$ の氷の崖が続き オラフ海岸とちがつて非常にゆるやかな傾斜で内部へ続いている。海岸には露岩なく, 僅かに内陸に数個 の露崖を見ただけである。この露岩は米軍の写真写つていたものと同一のものと思われるが，はつきり

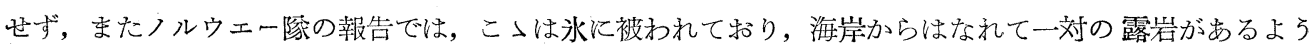
に書いているが，果して同一のものかぞうかははつきりしない。

この海岸は, 前述の如く氷崖で, 海水またはオープンシーに接しているが, 東のリュツオホルム湾に面 したところは,だんだんに氷崖が低くなり,その先は写真の如くかまぼこ型の水が並んで海になつている。 この先とリュツオホルム湾奥北東部のフレッタ湾との間は残念ながら飛ぶ時閒がなからたために 今回はそ の状沅が調べられていない。 


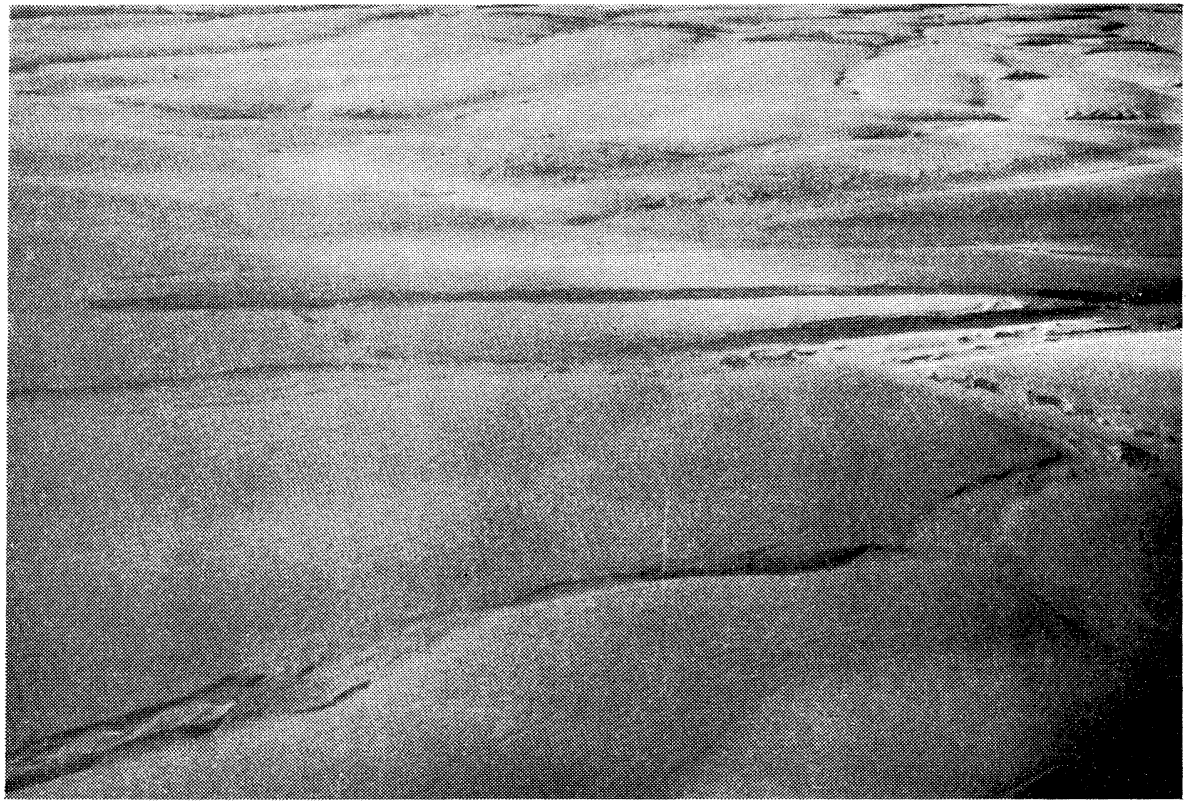

写真 9 クック岬菓岸の大陸氷の状態

1. 南極に和将る写真測量の諸問題

1）飛行機：セスナ 180 型「さち風」は非常に良く働いた。しかし，本格的な地図作成となると，このよ うな小型飛行機では非常に不経済な值用方法をとらざるを得なくなる。

連絡用とか，単に目で見るのみは偵察用として，この上うな飛行機は是非必要であるが，空中写真測量 用としては，もつと大型の飛行機で，双発以上の飛行機が欲しい。もちろん，大型飛行機となれば，それ に応じた人員，和よび燃料その他が必要になり，いろいろの問題がからんでくることになるが，写真測量 の立場からいえば，少くとも 2 台の写真機，できれば 3 台の写真機を設置できる。すなわち，ビイカメ ラ，またはトリカメラシステムのとれる飛行機が欲しいのである。

1,300 万平方籸の南極大陸で一地方の測量を行うといつても，相当な面積になる。しかもこれを非常に 限られた時間内に行万となれば, どうしても上記のような方法をとらざるを得ないのである。しかも飛行 機はこの他に少くとも 3 人の乗員，パイロット・ナビゲーター・撮影士を乗せ，この 3 人の非常用の食 糧・装備をつんで飛ぶことが必要である。特に大陸内部に大るとなれば，非常の場合を考兄ても 3 人の人 員といらのは絶対必要で, この 3 人の 3 週間位の生活物資を必要とするだろうと思わ礼る。

また，短い時間で仕事を行 $と$ とらことを考光れば，高速度・長い航続距離をもち，さらに内陸へ向つ てどんどん高くなつている大陸水を考光れば，赛用上昇限度の高いものでなくてはならない。

こう考觉ると, 単発の飛行機で行える限界というものは怙のずから定まり, せいぜい $250 \mathrm{~km}$ の範囲ま でで，この限界を越すことは仮りにそれ以上の性能をもつていても，心理的な問題も含めて一寸無理なの ではないだろうか。 $250 \mathrm{~km}$ とい光ばこれは昭和基地から南極点までの距離の約 10 分の 1 でしかないので ある。

この他に飛行機については，たとえば低翼はブリザードの時に困るとか，色は赤や黄色に鉒つた方が良 いとか，エンジン始動の問題等について各国の報告があるが，幸いにセスナ 180 は高翼であり，機体や翼 は赤に塗つてあつた。またエンジンの始動については，2，3 回熱風送風機で暖めたことがあるが，大体夏 
のもつとも気温の高い時期であつたためか，普通行行つて別に支障がなかつたようである。

2) カメラ：便用した主なるカメラは K $17 \mathrm{C}$ と F 24 で山るが，K $17 \mathrm{C}$ が一寸電気部分が具合が悪く なつただけで，別に卖障なく便えた。

特に低温を予想して，カメラ用電気ヒータージヤケットまで用意したのであるが， $2,000 \mathrm{~m}$ の高度で 一 $7^{\circ} \mathrm{C}$ であり，別用いるほどのこともなかつた。

たよ゙ F 24 は最初の計画では $33^{1} / 4^{\prime \prime}$ の焦点距離の広角レンズを入手しようとしたのであるが，時間がな

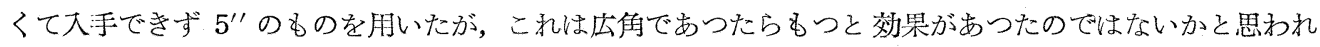
る。

たざこの二つのカメラに共通してい光る久点は，時間・高度・写真番号等が自動的に記録されないとい らことである。この他飛行機の針路・速度等も別の $35 \mathrm{~mm}$ または $16 \mathrm{~mm}$ の撮影機を使用しても良い から記鉎されたら非常に便利だろらと思われる。

その他，レーダーアルテイメーターや電波によつて飛行機の位置がわかり，それが一緒に記録されれば 非常に図化の際に役立つるのと思われる。

3）露出と写真処理： K $17 \mathrm{C}$ の平均露出は，使用したフイルムの感光度が ASA 100 であるが，F 11 で1/400,フイルターはマイナスブルーである。しかし露岸地带と氷雪のところでは露出はかなり違い, 相当 に変光ざるを得なかつた。このため F 11 で $1 / 400$ から F $6.3 て ゙ 1 / 100$ までの露出を撮影時間・天候によつ て適当使用した。露出計も使用したが，これは決定的なものとして使用せず，単代試験的用いたの及 であるが，少し工夫をすれば，充分使えるようになるのではないかと思われる。

F 24 では F 8，1/400 が平均露出であつたが，F 4 で $1 / 300$ とい5のも大分用いた。これは斜写真で非常 に太陽の低い時にとつたことがあるからで，この時は晲像液を濃くして用いた。

現像は，国内で D 76 液 $10 l$ 用に調合したものを持つて行き，すべて船内で行つたが，これは狭い船内 で行うのに非常に有效であつた。水はすべて，イオン交換を行つたものを用い，水洗はハイポ駆除剤を用 いて水を節約した。時に氷の中のパドルの水はそのまつは使わず必ずイオン交換を行ら必要があるようで ある。現像時間は 20〜30 分であつたが，先に述べた F 24 の夜の撮影の時は 2 倍の濃度で 40 分行つた。

この写真処理は偵察用の写真の焼付けを含めて, 船内で行つた量は相当多いのであるが, 宗谷の暗室は 狭く, 空中写真の処理には不充分だつたので, 適当な場所を見つけては或いは浴場で, 或いは医務室で行 つた。もつとも困つたのは乾燥で, これは乾燥機が積荷の都合と, 適当な場所がないので使用できず, 夜 の降員の睡眠時間を利用して，隊員食堂で自然乾燥を行つた。しかし，K 17 のフイルムは $4 \mathrm{~kg}$ もり一 寸取披いに不便だつた。これも是非專門の写真処理を行う人が欲しいものであるが，現像しないで国内へ るちか觉ることも本観測では当然考皃なくてはならない問題である。

4）フイルム：K17C にはコダックスーパーXX を胕い，国産の富士，さくらの航空フイルムをそれ ぞれ 2 本ずつるつていつたのであるが使用する時間なく, そのま〉もち帰つた。これは是非試験的に使用 したいと思つていたのであるが，残念ながらその機会にめぐまれなかつた。

F 24 はすべてさくら航空フイルムを用いた。カラーフイルムを使用してみるのも，氷河や地理・地質の 部門からみると面白い結果が得られるのではないかと思われる。

基淮点測量についてはヘリコプター使用によつて基淮点間隔を增すことを考光ると共に飛行機自体の位 置を正確に知る方法を考孚る必要があるのではないかと思う。特にッーラートリアンギュレーションと電 波による方法は充分考慮する価值があると思われる。これは大型機を使つた場合に当然起る問題で, 写真 撮影にくらべて，地上基準点の設置は非常に時間がかつるために，是非，飛行機上でその位置を記録する ことを考皇なくてはならないと思う。 


\section{V. 帰国後の図化}

今回の観測で得た結果は，K $17 \mathrm{C}$ による重直写真 791 枚, F 24 による斜写真 463 枚, 基淮点は天測点 を含めて 9 点である。

とりあえず，本観測の計画用に，基地附近の千分の 1 と東オングル島の 5 千分の 1 の地図をウイルド・ ステレオプロッターA 8で作つた。この図化はすべて基準点があるところであり，精度は非常に高いもの である。

この他に，ッアイスのステレオプラニグラフC 8 による空中三角測量も二ニース西オングル島で行つた が, これは，終端に基淮点がないために若干精度が㸓ると思われる。

幸いに，水面がところどころにあり，これで高さの点検は行えた。この空中三角測量は，まだ作業中で あり，今のところは，はつきりした結果がでていないが，南極の地図としては充分な精度をもつていると 思われる。

図化にあたつては，植生がなく，等高線は描きやすいが，海岸線のとり方には悩まされる。そこで，今 回は，海水汇続く部分は，タイドクラックが写真上に明膫にあらわ机ているので，この線をとつて，海岸 線の代用にした。また，露岩は，褐色の等高線で描き，氷の地域は，青色の点線で囲み，この部分の等高 線は青色にした。この他，註記等は黒色と三色刷にしたのであるが，附図は，これを，7千5百分の1に 縮め, 一色にしたものである。

\section{VI. 結 論}

今回の予備観測では, 撮影飛行は，1月14 日から行い，2月1日に終るまで, 僅が 9 回, 飛行時間 は，延 21 時間 55 分に過ぎなかつたが，天候が，予想したよりもずつと良かつたので，目的の仕事は充分 行えた。

しかし，南極大陸全体からみれば，非常に狭い範国であり，今回の経験を生かして，本観測では，昭和 基地から, エンダービランドにいたるプリンスオラフ海岸, さらにプリンスハラルド海岸の 米軍の写真の ある地域をでを，垂直写真撮影を行つて図化したいのであるが，地図を作るために，専用の空中写真撮影 用飛行機と，これにともなら，人員がなければ困難であろう。

また，もつとも，時間がかつる基準点測量については，ヘリコプターを基準点測量の輸送に用いても, 写真撮影に応ずるだけの基準点設置は，困難だろうと思われ，先に述べたような電波や，ソーラートリア ンギュレーションも，現状では，実現困難であろらから，撮影コースで三角形，または，四辺形を描き， これで, 空中三角測量を行つて，閉塞点で点検を行なうといら方法をとるのが，もつとも良いように思え る。

このような方法が行えれば，南極大陸の地図としては充分満足のできるものが作れるだらう。 
東オングル島 EAST ONGUL I.

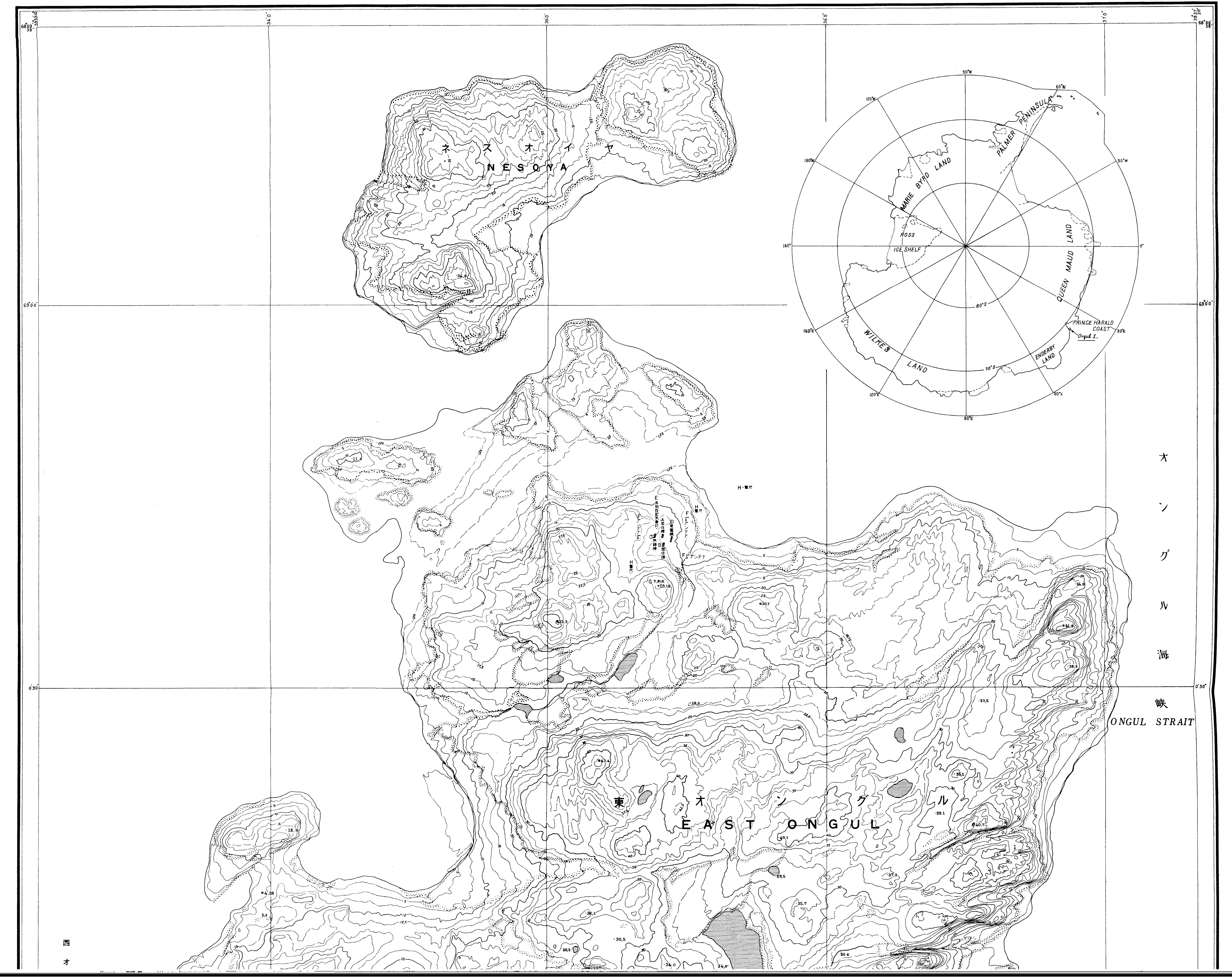

